\section{Growth and Yield of Broccoli as Affected by the Nitrogen Content of Transplants and the Timing of Nitrogen Fertilization}

\author{
Carmen Feller and Matthias Fink \\ Institute of Vegetable and Ornamental Crops Großbeeren and Erfurt, Theodor \\ Echtermeyer Weg, D-14979 Großbeeren, Germany
}

Additional index words. Brassica oleracea var. italica, field vegetable

\begin{abstract}
The nitrogen requirement of broccoli (Brassica oleracea var. italica) ranges from 300 to $465 \mathrm{~kg} \cdot \mathrm{ha}^{-1}$. Recommendations for $\mathrm{N}$ fertilization are accordingly high. High fertilizer rates applied at planting result in a high soil mineral $N$ content that remains high for weeks because the $\mathrm{N}$ requirement of the crop is low at early growth stages. Therefore, the risk of leaching is high for several weeks until the available $\mathrm{N}$ is finally taken up by the crop. Our study had two objectives: 1) to quantify yield responses to preplant fertilization, and 2) to test our hypothesis that the preplant fertilization rate could be reduced without yield losses by increasing the $\mathrm{N}$ content in the transplants and improving crop establishment. Field experiments were carried out on transplants with four levels of $\mathbf{N}$ content in dry matter $\left(0.018\right.$ to $0.038{\mathrm{~g} \cdot \mathrm{g}^{-1}}^{\mathrm{dry}}$ weight $)$, which were tested in all combinations with four fertilization timings. All treatments received the same amount of $\mathrm{N}$ fertilizer (270 and $272 \mathrm{~kg} \cdot \mathrm{ha}^{-1}$ in 2001 and 2002 , respectively), but with different rates of supply at the time of planting (0 to $90 \mathrm{~kg} \cdot \mathrm{ha}^{-1} \mathrm{~N}$ fertilizer plus 30 and $28 \mathrm{~kg} \cdot \mathrm{ha}^{-1}$ soil mineral $\mathrm{N}$ in 2001 and 2002, respectively). Total and marketable yields increased significantly with an increasing $\mathbf{N}$ supply at time of planting. In our experiments, in which topdressing was applied 25 days after planting, an $\mathrm{N}$ supply at planting of 80 to $118 \mathrm{~kg} \cdot \mathrm{ha}^{-1}$ was required to obtain maximum marketable yields. The $N$ content in transplants had little effect on growth and yield, and there were no significant interactions between the $\mathbf{N}$ content in the transplant and fertilizer timing.
\end{abstract}

The $\mathrm{N}$ requirement of broccoli ranges from $300 \mathrm{~kg} \cdot \mathrm{ha}^{-1}$ (Everaarts and de Willingen, 1999a) to $465 \mathrm{~kg} \cdot \mathrm{ha}^{-1}$ (Zebarth et al., 1995). Therefore, recommended fertilizer application rates are generally high, despite fertilizer recommendations often being lower than plant requirements. This is because both the mineral $\mathrm{N}$ present in the soil at time of planting (Hochmuth, 2003; Wehrmann and Scharpf, 1986) and expected N mineralization (Fink and Scharpf, 2000) needs to be taken into account.

Although the yield response of broccoli to the total rate of $\mathrm{N}$ fertilization has been reported in a number of studies (Zebarth et al., 1995, and references therein), there is no agreement on the possible benefits and drawbacks of strategies for the timing of fertilizer applications during the growth period. For instance, Everaarts and De Willingen (1999b) recommended the application of the required fertilizer in a single dose at the time of planting, whereas Bowen et al. (1999) reported that it is a general recommendation to growers in British Columbia, Canada, to apply $\mathrm{N}$ fertilizer in a split application, half at the time of transplanting, and the remainder 2 weeks later. The intention of the

Received for publication 23 Nov. 2004. Accepted for publication $19 \mathrm{Feb}$. 2005. The authors wish to thank U. Hoffmann for her skillful technical assistance. Financial support from the Ministries of Agriculture of the Federal Republic of Germany, and from the states of Brandenburg and Thuringen is also gratefully acknowledged. split application was to provide sufficient $\mathrm{N}$ for inflorescence development without applying excessive fertilizer early, when it could burn young plants. However, Bowen et al. (1999) concluded from their own experiments that the planting. practice of splitting $\mathrm{N}$ fertilizer application is unnecessary because they did not find evidence that applying ammonium nitrate at rates up to $312 \mathrm{~kg} \cdot \mathrm{ha}^{-1}$ at planting was detrimental to broccoli. Weier (1992) suggested the provision of at least $30 \%$ of the crop's total $\mathrm{N}$ requirement at planting because fertilizer treatments with lower basal dressings resulted in lower yields in her experiments. However, Belec et al. (2001), who compared three $\mathrm{N}$ supply rates at planting, combined with four $\mathrm{N}$ rates 5 weeks later, found that although the marketable yield was significantly affected by the total fertilizer applied, the effects of fertilizer timing within one level of fertilizer were negligible.

It should be noted that fertilizer timing could affect not only plant growth, but also $\mathrm{N}$ use efficiency. Based on experiments with sown broccoli, Thompson et al. (2002) disapproved preplant applications that might be inefficiently used because of a low plant requirement during the early growth period. Fink et al. (2001) reported an average $\mathrm{N}$ requirement of only 20 $\mathrm{kg} \cdot \mathrm{ha}^{-1}$ during the first 3 weeks after planting. Such a low N requirement of the crop, in combination with high fertilizer rates before planting, result in a high soil mineral $\mathrm{N}$ content that is prone to leaching for several weeks until taken up by the plants. Therefore, the risk of $\mathrm{N}$ loss from leaching could be reduced by low preplant fertilization.

Our study had two objectives: 1) to quantify yield response to preplant fertilization, and 2) to test our hypothesis that preplant fertilization rates could be reduced without yield losses by increasing the $\mathrm{N}$ content in the transplants.

\section{Materials and Methods}

Seedlings of 'Marathon' broccoli (Sakata Seed Corp., Japan), were grown in a greenhouse in multicellular trays $\left(42 \mathrm{~cm}^{3}\right.$ per cell) filled

Table 1. $\mathrm{N}$ application during transplant cultivation, $\mathrm{N}$ content, and dry matter of transplants at time of

\begin{tabular}{|c|c|c|c|c|c|c|c|}
\hline \multirow[b]{3}{*}{ level } & \multirow[b]{3}{*}{ Year } & \multicolumn{4}{|c|}{$\begin{array}{l}\mathrm{N} \text { application } \\
\left(\mathrm{mg} \cdot \mathrm{L}^{-1}\right)\end{array}$} & \multirow{3}{*}{$\begin{array}{c}\mathrm{N} \\
\text { content } \\
\left(\mathrm{g} \cdot \mathrm{g}^{-1}\right)\end{array}$} & \multirow{3}{*}{$\begin{array}{c}\text { Dry } \\
\text { matter } \\
\text { (g/plant) }\end{array}$} \\
\hline & & \multicolumn{4}{|c|}{ Days } & & \\
\hline & & 1 & 4 & 8 & 12 & & \\
\hline$\overline{1}$ & 2001 & 75 & 0 & 0 & 0 & 0.021 & 0.17 \\
\hline 2 & 2001 & 75 & 75 & 75 & 0 & 0.026 & 0.20 \\
\hline 3 & 2001 & 75 & 150 & 150 & 75 & 0.030 & 0.23 \\
\hline 4 & 2001 & 75 & 225 & 225 & 150 & 0.038 & 0.23 \\
\hline 1 & 2002 & 75 & 0 & 0 & 0 & 0.018 & 0.17 \\
\hline 2 & 2002 & 75 & 75 & 75 & 0 & 0.023 & 0.19 \\
\hline 3 & 2002 & 75 & 150 & 150 & 75 & 0.028 & 0.23 \\
\hline 4 & 2002 & 75 & 225 & 225 & 150 & 0.032 & 0.29 \\
\hline
\end{tabular}

${ }^{\mathrm{z}} \mathrm{N}$ applied on days $1,4,8$, and 12 after the second true leaf became visible (see text).

Table 2. Soil nitrate $\mathrm{N}$ at planting $(0$ to $0.3 \mathrm{~m})$ and fertilizer timing. All treatments received a total $\mathrm{N}$ fertilization of $270 \mathrm{~kg} \cdot \mathrm{ha}^{-1}$ in 2001 and $272 \mathrm{~kg} \cdot \mathrm{ha}^{-1}$ in 2002 (i.e., a total $\mathrm{N}$ supply of $300 \mathrm{~kg} \cdot \mathrm{ha}^{-1}$ ).

\begin{tabular}{|c|c|c|c|c|c|c|}
\hline \multirow[b]{3}{*}{ Treatment } & \multirow[b]{3}{*}{ Date } & \multirow[b]{3}{*}{ Year } & \multicolumn{4}{|c|}{$\mathrm{N}$ fertilizer distribution } \\
\hline & & & \multicolumn{4}{|c|}{ Treatment $\left(\mathrm{kg} \cdot \mathrm{ha}^{-1}\right)$} \\
\hline & & & 1 & 2 & 3 & 4 \\
\hline Soil nitrate $\mathrm{N}$ & May 10 & 2001 & 30 & 30 & 30 & 30 \\
\hline Base fertilization & May 14 & 2001 & 0 & 50 & 70 & 90 \\
\hline First top fertilization & June 9 & 2001 & 135 & 110 & 100 & 90 \\
\hline Second top fertilization & June 21 & 2001 & 135 & 110 & 100 & 90 \\
\hline Soil nitrate $\mathrm{N}$ & May 6 & 2002 & 28 & 28 & 28 & 28 \\
\hline Base fertilization & May 15 & 2002 & 0 & 50 & 70 & 90 \\
\hline First top fertilization & June 10 & 2002 & 136 & 111 & 101 & 91 \\
\hline Second top fertilization & June 21 & 2002 & 136 & 111 & 101 & 91 \\
\hline
\end{tabular}


with a mixture of white peat and fine bark. The initial nutrient content of the substrate was 152 $\mathrm{mg} \cdot \mathrm{L}^{-1}$ extractable nitrogen, $65 \mathrm{mg} \cdot \mathrm{L}^{-1}$ phosphorus and $195 \mathrm{mg} \cdot \mathrm{L}^{-1}$ potassium. Nitrogen and phosphorus were measured spectrophotometrically(EPOS 5060; Eppendorf, Hamburg, Germany). Potassium was measured using a flame atomic emission spectrometer (AAS vario 6; Carl Zeiss Jena, Germany). Seedlings were watered every day, and in addition, containers were saturated with a nutrient solution on days $1,4,8$, and 12 after the second true leaf had become visible. The $\mathrm{N}$ concentration of the applied solution and the resulting $\mathrm{N}$ contents in the transplants are shown in Table 1. At the time of planting, 80 transplants at each level of $\mathrm{N}$ supply were taken. The dry matter (dried at $65^{\circ} \mathrm{C}$ ) and $\mathrm{N}$ content (measured with an Auto Analyser, Heraeus, Germany) of transplants are shown in Table 1.

Field experiments were carried out on a sandy soil, an Arenic Luvisol (World Reference Base), with 10.8 and $11.1 \mathrm{mg} \cdot \mathrm{g}^{-1}$ organic matter in 2000 and 2001, respectively. The two-factor experiments were Latin rectangle designs with four levels of transplant $\mathrm{N}$ content (Table 1) and four $\mathrm{N}$ fertilization strategies (Table 2). Fertilizer was applied broadcast as calcium ammonium nitrate. All 16 factorial combinations were replicated four times.

The field plot size was $5.0 \times 4.8 \mathrm{~m}$. Transplants were planted on 15 May 2001 and 16 May 2002, and each plot contained 10 rows, which were $0.5 \mathrm{~m}$ apart. Plants were $0.4 \mathrm{~m}$ apart within a row, which resulted in a plant density of $50000 \mathrm{plants} / \mathrm{ha}$. Ten plants per plot were sampled $25 \mathrm{~d}$ after planting, to assess early development. When $80 \%$ of the heads reached a marketable growth stage, 32 plants from a 6.4 $\mathrm{m}^{2}$ central portion of each plot were harvested to determine marketable yield.

Heads were considered marketable when the diameter was greater than $0.12 \mathrm{~m}$ and the maturity index was in the range of 3 to 5 . The broccoli maturity index was suggested by Sorensen and Grevsen (1994). The index range from 1 (no visible head) to 7 (flowering). Index 4 (fully developed firm head) denotes the developmental stage with optimal market quality. Heads were cut to $17 \mathrm{~cm}$ length and leaves were removed.

Soil nitrate $\mathrm{N}$ was measured from 16 auger samples taken from soil layers of 0 to $0.3 \mathrm{~m}$ and 0.3 to $0.6 \mathrm{~m}$. Soil samples were taken from the whole field at the time of planting and from each plot separately at harvest date. After extraction with $0.0125 \mathrm{M} \mathrm{CaCl}_{2}$, nitrate $\mathrm{N}$ was determined spectrophotometrically (EPOS, Eppendorf, Germany).

Sprinkler irrigation was applied according to the irrigation scheduling computer program BEREST (Gutezeit et al., 1993). The program calculated soil water content in the rooted soil layer on a daily basis using the water holding capacity of the soil, plant growth stage, and potential evapotranspiration as input variables. Irrigation decisions were made on the basis of the calculated soil water content and the expected evapotranspiration and precipitation of the next $5 \mathrm{~d}$.

Analysis of variance, measures of dispersion, and the Tukey test procedure $\left(\mathrm{HSD}_{P=0.05}\right)$ were calculated using a statistics program (STATISTICA, StatSoft Inc. 2001, Tulsa, Okla.).

\section{Results and Discussion}

Although the $\mathrm{N}$ supply (soil nitrate $\mathrm{N}$ at planting date $+\mathrm{N}$ fertilizer) was almost identical in 2001 and 2002, both total fresh weight (Figs. 1 and 2) and marketable yield (Table 3) showed considerable differences between years. The differences were probably caused by different temperature time courses, which have a major impact on the growth and yield of broccoli (Thompson et al., 2002; Zebarth et al., 1995). Although the average air temperature during the entire cultivation period was only slightly higher in 2002 , at $17.6^{\circ} \mathrm{C}$, compared to $16.1^{\circ} \mathrm{C}$ in 2001 , the temperature time courses were quite different between years. The average air temperature in the first $25 \mathrm{~d}$ after planting

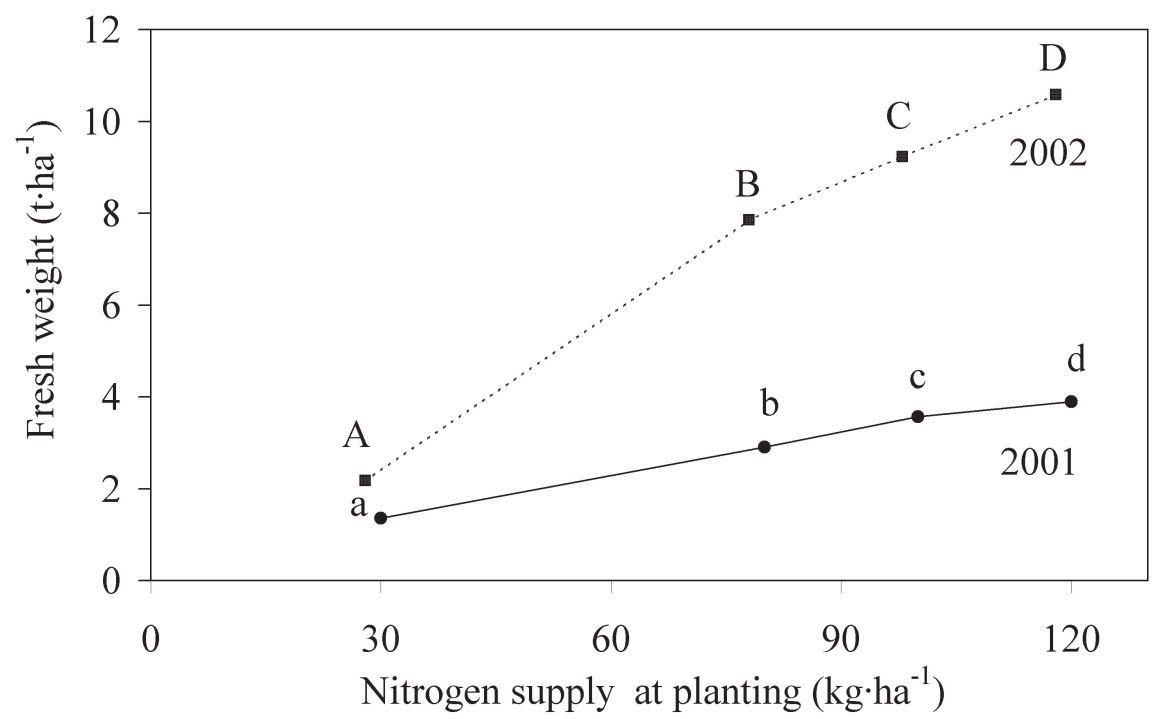

Fig. 1. Effect of $\mathrm{N}$ supply at planting on above ground fresh weight at harvest. $\mathrm{N}$ supply was calculated as the sum of soil nitrate $\mathrm{N}$ ( 0 to $0.3 \mathrm{~m})$ at time of planting plus $\mathrm{N}$ base fertilization in 2001 and 2002. Different letters show significant differences within 1 year.

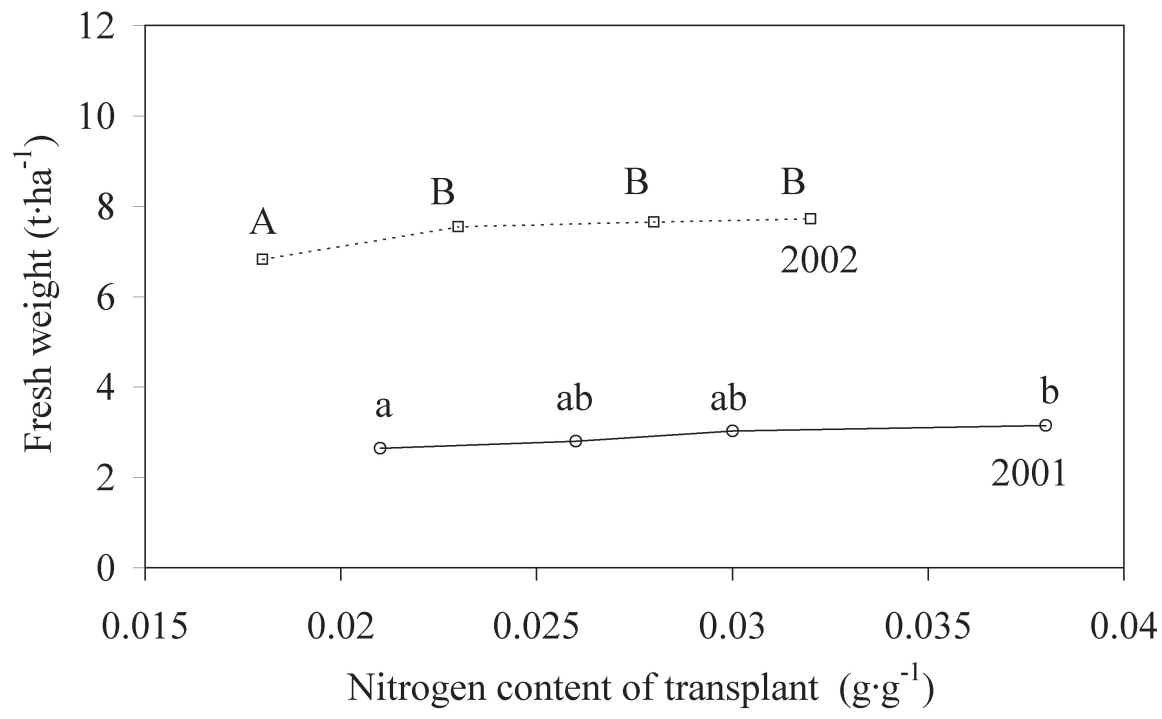

Fig. 2. Effect of $\mathrm{N}$ content in the transplant on above ground fresh weight at harvest in 2001 and 2002. Different letters indicate significant differences within 1 year. was higher in 2002 , at $16.4{ }^{\circ} \mathrm{C}$, compared to $14.5^{\circ} \mathrm{C}$ in 2001 , which increased the average Therefore, the first flower buds were visible $25 \mathrm{~d}$ after planting in 2002, and $31 \mathrm{~d}$ after planting in 2001. During the last week before harvest in 2002, above optimal maximum day temperatures occurred, at $30.4{ }^{\circ} \mathrm{C}$, compared to $24.2^{\circ} \mathrm{C}$ in 2001 . This reduced the growth rate in 2002 and required an earlier harvest because the heads started to separate earlier, and buds started to bloom.

Analyses of variance did not show significant interactions between the $\mathrm{N}$ level in the transplant and fertilizer timing (Table 4). Therefore, our hypothesis that the growth of broccoli shortly after planting could be inceasing the $\mathrm{N}$ content in the transplants, and thereby allow for a reduction in preplant fertilization without yield loss, was rejected. growth rate during early crop growth in 2002. 
Table 3. Effect of $\mathrm{N}$ content in transplant and $\mathrm{N}$ supply at planting on marketable yield.

\begin{tabular}{|c|c|c|c|c|c|}
\hline \multirow{2}{*}{$\begin{array}{l}\mathrm{N} \text { level } \\
\text { of } \\
\text { transplant }\end{array}$} & \multicolumn{2}{|c|}{$\begin{array}{l}\text { Marketable } \\
\text { yield }\left(\mathrm{t} \cdot \mathrm{ha}^{-1}\right)\end{array}$} & \multirow{2}{*}{$\begin{array}{c}\text { Level of N } \\
\text { supply at } \\
\text { planting }\end{array}$} & \multicolumn{2}{|c|}{$\begin{array}{l}\text { Marketable } \\
\text { yield }\left(\mathrm{t}^{-1} \mathrm{a}^{-1}\right)\end{array}$} \\
\hline & 2001 & 2002 & & 2001 & 2002 \\
\hline 1 & 17.1 & 11.4 & 1 & 13.4 & 6.3 \\
\hline 2 & 18.6 & 12.3 & 2 & 19.1 & 13.9 \\
\hline 3 & 19.0 & 13.9 & 3 & 20.5 & 14.4 \\
\hline 4 & 19.0 & 13.2 & 4 & 20.7 & 16.5 \\
\hline Tukey $\operatorname{HSD}_{(P=0.05)}$ & 1.9 & 1.8 & & 1.9 & 1.8 \\
\hline
\end{tabular}

Table 4. Analysis of variance.

\begin{tabular}{|c|c|c|c|c|c|}
\hline \multirow[b]{2}{*}{ Source } & \multirow[b]{2}{*}{$\mathrm{df}$} & \multicolumn{2}{|c|}{ Marketable yield } & \multicolumn{2}{|c|}{ Total yield } \\
\hline & & 2001 & 2002 & 2001 & 2002 \\
\hline 1, $\mathrm{N}$ level of transplant & 3 & $*$ & $*$ & NS & NS \\
\hline 2, Fertilizer timing & 3 & $*$ & $*$ & $*$ & * \\
\hline Interaction $(1 \times 2)$ & 9 & NS & NS & NS & NS \\
\hline Error & 42 & & & & \\
\hline
\end{tabular}

NS,"Nonsignificant or significant at the 0.05 probability level.

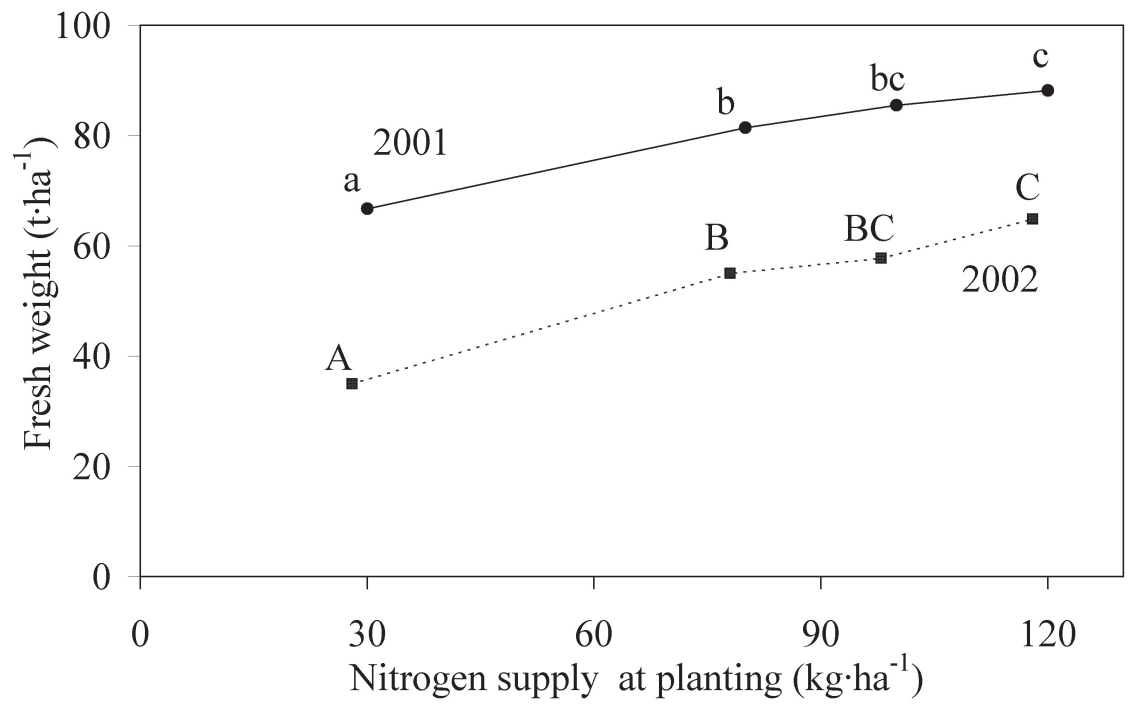

Fig. 3. Effect of $\mathrm{N}$ supply at planting on above ground fresh weight $25 \mathrm{~d}$ after planting in 2001 and 2002 . N supply was calculated as the sum of soil nitrate $\mathrm{N}(0$ to $0.3 \mathrm{~m})$ at time of planting plus $\mathrm{N}$ base fertilization. Different letters show significant differences within 1 year.

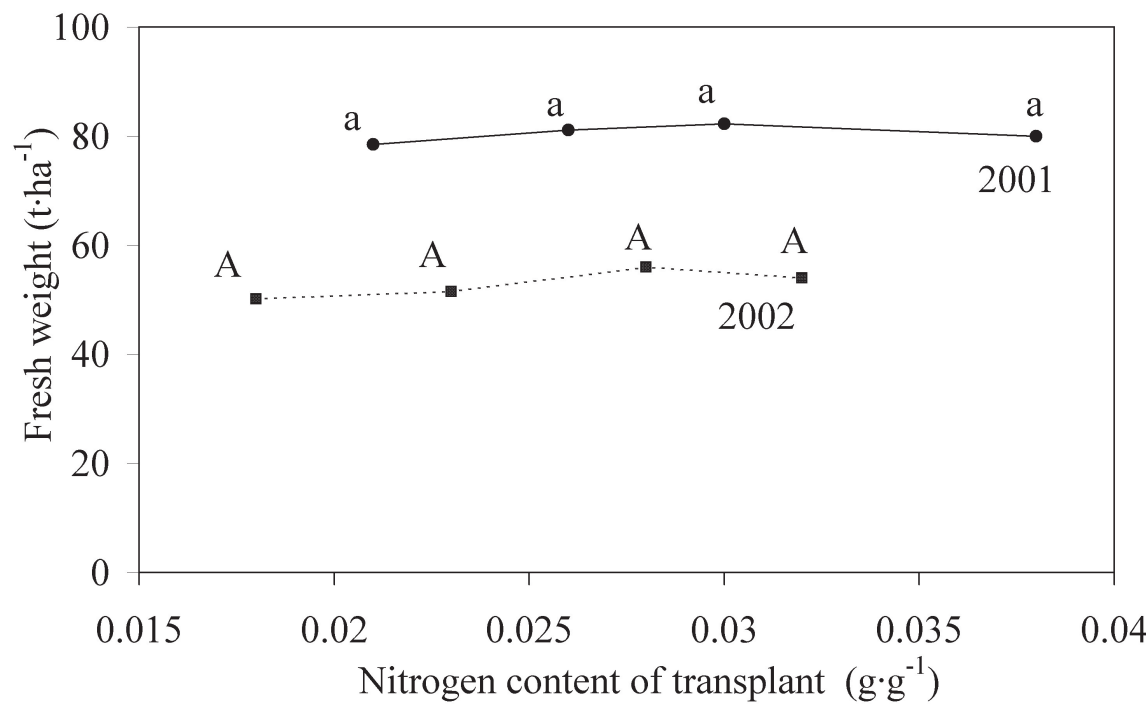

Fig. 4. Effect of $\mathrm{N}$ content in the transplant on above ground fresh weight $25 \mathrm{~d}$ after planting in 2001 and 2002. Different letters indicate significant differences within 1 year.
Because we did not find significant interactions, the following analysis only considers main factor effects.

Fertilizer distribution. Marketable yield and total yield were significantly affected by fertilizer timing (Table 4).

It should be noted that at the early sampling date in both years, treatments with an $\mathrm{N}$ supply of $120 \mathrm{~kg} \cdot \mathrm{ha}^{-1}$ resulted in significantly higher growth rates than treatments with $100 \mathrm{~kg} \cdot \mathrm{ha}^{-1}$ (Fig. 3). However, the maximum $\mathrm{N}$ uptake by the plants until $25 \mathrm{~d}$ after planting was only 6 to $21 \mathrm{~kg} \cdot \mathrm{ha}^{-1}$ and 12 to $61 \mathrm{~kg} \cdot \mathrm{ha}^{-1}$ in 2001 and 2002, respectively.

Previous studies with brassica crops showed that the $\mathrm{N}$ supply must often exceed plant requirement to obtain maximum yields (Everaarts, 2000; Fink, 2001; Sanchez et al., 1996). This is because plants could not always access the mineral $\mathrm{N}$ in the soil. Heins and Schenk (1987) determined that N uptake and growth of kohlrabi (Brassica oleracea var. gongylodes L.) was not limited by the nitrate concentration in the soil as long as it was higher than $10 \mathrm{~kg} \cdot \mathrm{ha}^{-1}$ in a well-rooted 0 to $0.3 \mathrm{~m}$ soil layer. However, higher values could be expected if roots and $\mathrm{N}$ are not homogeneously distributed in the soil (Heins and Schenk, 1987). This is obviously the case when fertilizer is applied broadcast and roots of transplants only colonize a small part of the soil. The effect of increasing $\mathrm{N}$ supply on the growth rate was already significant $25 \mathrm{~d}$ after planting. The differences between treatments persisted until harvest date, although low applications at planting were compensated for by higher topdressings, i.e., all treatments received the same total amount of fertilizer. The lowest $\mathrm{N}$ supply at planting, i.e., when no fertilizer was applied at planting, resulted in marketable yield losses of $13 \%$ in 2001 and $10 \%$ in 2002, when compared to the maximum yield of each year (Table 3 ). Marketable yields increased significantly with increasing preplant $\mathrm{N}$ supply up to 80 and $118 \mathrm{~kg} \cdot \mathrm{ha}^{-1}$ in 2001 and 2002, respectively.

Fertilizer was applied broadcast, which is common practice in Europe. Banded applications, as is customary in other regions, might have increased nitrogen use efficiency and might have lead to different results.

Nitrogen content of transplants. The $\mathrm{N}$ content in the transplants had little effect on crop growth (Figs. 2 and 4) and marketable yield (Table 3 ).

Transplants used for field experiments (for example, by Vagen et al., 2004), or transplants provided by commercial growers (data from an unpublished survey carried out in Germany), commonly contain $2.4 \%$ to $4.8 \% \mathrm{~N}$. In our experiments with transplants in the range of $1.8 \%$ to $3.8 \% \mathrm{~N}$, only treatments with the lowest $\mathrm{N}$ level $(<2.5 \% \mathrm{~N})$, in which the plants showed visible symptoms of $\mathrm{N}$ deficiency, had significantly lower growth rates up to $25 \mathrm{~d}$ after planting. The response of marketable yield at harvest date largely mirrored the response of growth up to $25 \mathrm{~d}$ after planting (Fig. 4). The lowest $\mathrm{N}$ level in the transplants resulted in marketable yield losses of $10 \%$ in 2001 and $24 \%$ in 2002 , when compared to the maximum yield of each year (Table 3 ). Total fresh weight 
at harvest was not significantly affected by the $\mathrm{N}$ content in the transplants (Table 4, Fig. 2). Our results agree with previous studies, where different transplant treatments had little effect on broccoli yield (Lamont, 1992, size and transplant age; Dufault and Waters, 1985, container size; Latimer, 1990, drought and mechanical stress). In contrast, Masson et al. (1991) who used fertigation solutions in the $\mathrm{N}$ range between 100 and $400 \mathrm{mg} \cdot \mathrm{L}^{-1}$, found that marketable yield increased linearly with increasing rates of $\mathrm{N}$ fertilization to transplants.

\section{Summary and Conclusions}

To reduce the risk of $\mathrm{N}$ loss by leaching during the early growth phase of broccoli, $\mathrm{N}$ fertilizer should be applied as a split application. However, too low an application at planting results in strongly decreased total and marketable yields. In our experiments, when topdressing was applied $25 \mathrm{~d}$ after planting, an $\mathrm{N}$ supply at planting of 80 to $118 \mathrm{~kg} \cdot \mathrm{ha}^{-1}$ was required to obtain maximum marketable yields. The $\mathrm{N}$ content of transplants had little effect on growth and yield, and there were no significant interactions between the $\mathrm{N}$ content in the transplant and fertilizer distribution.

\section{Literature Cited}

Belec, C., S. Villeneuve, J. Coulombe, and N. Tremblay. 2001. Influence of nitrogen fertilization on yield, hollow stem incidence and sap nitrate concentration in broccoli. Can. J. Plant Sci. 81:765-772.
Bowen, P.A., B.J. Zebarth, and P.M.A. Toivonen. 1999. Dynamics of nitrogen and dry-matter partitioning and accumulation in broccoli (Brassica oleracea var. italica) in relation to extractable soil inorganic nitrogen. Can. J. Plant Sci. 79:277-286.

Dufault, R.J. and L. Waters. 1985. Container size influences broccoli and cauliflower transplant growth but not yield. HortScience 20:682-684.

Everaarts, A.P. and P. De Willigen. 1999a. The effect of nitrogen and the method of application on yield and quality of broccoli. Neth. J. Agr. Sci. 47:123-133.

Everaarts, A.P. and P. De Willigen. 1999b. The effect of the rate and method of nitrogen application on nitrogen uptake and utilization by broccoli. Neth. J. of Agr. Sci. 47:201-214.

Everaarts, A.P. 2000. Nitrogen balance during growth of cauliflower. Scientia Hort. 83:173-186.

Fink, M. and H.C. Scharpf. 2000. Apparent nitrogen mineralization and recovery of nitrogen supply in field trials with vegetable crops. J. Hort. Sci. Biotechnol. 75:723-726.

Fink, M., C. Feller, H.C. Scharpf, U. Weier, A. Maync, J. Ziegler, J. Schlaghecken, P.-J. Paschold, and K. Strohmeyer. 2001. Düngung im Freilandgemüsebau. Institut für Gemüse- und Zierpflanzenbau Großbeeren/Erfurt. Gartenbauliche Berichte (4).

Fink, M. 2001. Yield and external quality of kohlrabi as affected by soil mineral nitrogen residue at harvest. J. Hort. Sci. Biotechnol. 76:419-423.

Gutezeit, B., F.-N. Herzog, and K.-O. Wenkel. 1993. Das Beregnungsbedarfssystem für Freilandgemüse. Gemüse. 29:106-108.

Heins, B. and M. Schenk. 1987. Root-growth and nitrate uptake of vegetable crops. J. Plant Nutr. 10:1743-1751.
Hochmuth, G.J. 2003. Progress in mineral nutrition and nutrient management for vegetable crops in the last 25 years. HortScience 38:999-1003.

Lamont, W.J. 1992. Transplant age has little effect on broccoli head weight and diameter. HortScience 27:848-848.

Latimer, J.G. 1990. Drought or mechanicalstress affects broccoli transplant growth and establishment but not yield. HortScience 25:1233-1235.

Masson, J., N. Tremblay, and A. Gosselin. 1991. Nitrogen fertilization and HPS supplementary lighting influence vegetable transplant production. I. transplant growth. J. Amer. Soc. Hort. Sci. 116:594-598.

Sanchez, C.A., R.L. Roth, B.R. Gardner, and H. Ayer. 1996. Economic responses of broccoli and cauliflower to water and nitrogen in the desert. HortScience 31:201-205.

Sorensen, L. and K. Grevsen. 1994. Effects of plant spacing on uniformity in broccoli for once-over harvest. Gartenbauwissenschaft 59:102-105.

Thompson, T.L., T.A. Doerge, and R.E. Godin. 2002. Subsurface drip irrigation and fertigation of broccoli: I. Yield, quality, and nitrogen uptake. Soil Sci. Soc. Amer. J. 66:186-192.

Vagen, I.M., A.O. Skjelvag, and H. Bonesm. 2004. Growth analysis of broccoli in relation to fertilizer nitrogen application. J. Hort. Sci. Biotechnol. 79:484-492.

Wehrmann, J. and H.C. Scharpf. 1986. The Nminmethod-An aid to integrating various objectives of nitrogen-fertilization. Zeitschrift für Pflanzenernährung und Bodenkunde 149:428-440.

Zebarth, B.J., P.A. Bowen, and P.M.A. Toivonen. 1995. Influence of nitrogen-fertilization on broccoli yield, nitrogen accumulation and apparent fertilizer-nitrogen recovery. Can. J. Plant Sci. 75:717-725. 